\title{
Genesis of dairy based farmer producer companies in Kerala
}

\author{
Elizabeth Jose, HR Meena and BS Meena
}

Received: 18 December 2018 / Accepted: 10 February 2019/ Published online: 18 April 2019

(C) Indian Dairy Association (India) 2019

\begin{abstract}
A study on the genesis of dairy based farmer producer companies was carried out in five companies of Kerala. From each company 24 members were randomly selected. Reasons behind the formation of company were analyzed statistically. The study revealed that 96.66 percent of respondents viewed better price realization through direct sale of farm produce by eliminating middleman as the foremost reason of company formation followed by availability of farm inputs at reasonable rate $(90.83 \%)$ and benefits from various government schemes (90.83\%) through producer company. Other important reasons were upgraded technology, reducing risk in farming, upliftment of women, value addition, capacity building and storage facility.
\end{abstract}

Keywords: Dairy, Farmer producer company, Genesis, Kerala

\section{Introduction}

Indian agriculture is predominantly characterized by large number of dispersed and fragmented small holdings. Around $85 \%$ of land holdings belong to small and marginal farmers. Being unorganized, these farmers are unable to realize good value for their produce.

Elizabeth Jose ( $\square)$, HR Meena, BS Meena

Dairy Extension Division, ICAR-National Dairy Research Institute,

Karnal -132001 (Haryana), India

E-mail: joseelizabeth987@gmail.com
Farmer Producer Companies (FPC) enable member farmers to reap the benefits of economies of scale in purchase of inputs, processing and marketing of their produce. FPC is said to be viable option for farmers to transformation agriculture in to a new profit oriented company. Because of increased political inference in cooperatives, farmers are not able to satisfy their needs. This paved the way for the birth of Farmer producer companies (Navaneetham et al, 2017). FPOs are farmers' collectives, with membership mainly comprising small/marginal farmers (around 70 to $80 \%$ ). Presently, around 5000 FPOs (including FPCs) are in existence in the country, which were formed under various initiatives of the Govt. of India (including SFAC), State Governments, NABARD and other organizations over the last 8-10 years. Of these, around 3200 FPOs are registered as Producer Companies and the remaining as Cooperatives/ Societies, etc. Majority of these FPOs are in the nascent stage of their operations with shareholder membership ranging from 100 to over 1000 farmers and require not only technical handholding support but also adequate capital and infrastructure facilities including market linkages for sustaining their business operations. With a view to encouraging enabling environment for aggregation of farmers into FPOs and take advantage of economies of scale, the Govt. announced $100 \%$ cent percent tax deduction for FPOs with annual turnover of up to Rs. 100 crores. (National Paper - PLP 2019-20, NABARD).

Farmer Producer Companies (FPC) are institutions that have all the significant features of private enterprises while incorporating principles of mutual assistance in their mandate, like co-operatives (Pustovoitova, 2011). But they differ from co-operatives in several other respects (Table 1). The basic purpose envisioned for the FPCs is to collectivize small farmers for backward linkages for inputs like seeds, fertilizers, credit, insurance, knowledge and extension services; and forward linkages like collective marketing, processing and market-led agriculture production (Mondal, 2010). While co-operatives entail benefits to farmers via state intervention, FPCs are perceived to empower farmers through collective bargaining, along with instilling an entrepreneurial angle to farming.

The Indian government is promoting the formation of FPCs.It is another form of business like co- operatives. In 2002, the 
Government of India amended the Companies Act, 1956, by incorporating part IX A, based on the recommendations of the Y. K. Alagh Committee (Mondal, 2010). Producer Companies are to be registered with the Registrar of Companies as limited companies formed with equity contribution from the members. The day-to- day operations are to be managed by professionals under the instructions of the Board of Directors elected by the General Body for a specified tenure (Mondal, 2010). The Department of Agriculture and Cooperation had issued a policy document titled "Policy and Process Guidelines for Farmer Producer Organizations" in 2013 to encourage the formation of FPCs. It also set out indicative guidelines for the formation and performance of these collectives (Department of Agriculture \& Cooperation, 2013). The primary evidence on FPCs in India indicate the potential to integrate small farms into the modern agricultural supply chains, increasingly dominated by large market players (Trebbin \&Hassler, 2012; Trebbin, 2014). Present study highlights the genesis of Dairy Based Farmers Producer Companies in Kerala.

\section{Materials and methods}

The present study was purposively conducted in Kerala state. Geographically Kerala divided in to three zones namely southern, central and northern (Padhmanabhan, 2011). Based on the information from NABARD Regional centre, Thiruvananthapuram, there were 11 animal based farmer producer companies working during July 2017-2018. Out of these 11 animal based farmers producer companies 5 dairy based farmer producer companies were selected purposively i.e. one from northern, two from central and two from southern region. These companies were located in the districts of Wayanad (northern zone), Palakkad (central zone), Idukki (central zone), Pathanamthitta (Southern zone) and Thiruvananthapuram (Southern zone).The ex-post facto research design was applied in this study. The producer companies had atleast 2 years of its existence. The respondents were selected on the basis of membership since last 2 years with particular company. Finally, 120 respondents were included in the study. In order to study genesis of company, producer company members were asked the evolution stages of that particular company and reasons for joining the producer company. Opinions were analyzed statistically using frequency and percentage.

\section{Results and discussion}

The reasons for formation of farmers producer companies and a brief description of genesis of each company are presented in

Table 1 significant differences between producer companies and co-operatives

\begin{tabular}{|c|c|c|}
\hline Parameters & Co-operatives & Producer Company \\
\hline Registration & Cooperative Societies Act & Indian Companies Act \\
\hline Area of Operation & Registered operational area & Entire Union of India \\
\hline Nature of Business & $\begin{array}{l}\text { Marketting,service and delivery } \\
\text { agencies }\end{array}$ & $\begin{array}{l}\text { Primarily agencies to provide marketing } \\
\text { solutions to pooled produce }\end{array}$ \\
\hline Membership & Based on ownership of land /residence & Based on concept of shareholding \\
\hline Share & Non-transferable & Transferable, limited to members on par value \\
\hline Governance & $\begin{array}{l}\text { Federated into the District } \\
\text { Cooperative Union/ Regional } \\
\text { cooperative Union } \\
\text {. Receive financial, } \\
\text { technical and administrative } \\
\text { support from the government }\end{array}$ & $\begin{array}{l}\text { Stand-alone, self-reliant } \\
\text { bodies with self-governing } \\
\text { capabilities }\end{array}$ \\
\hline Reserves & Created if there are profits & Mandatory \\
\hline Borrowing Power & $\begin{array}{l}\text { Restricted to loans granted and } \\
\text { disbursed by the co-operative } \\
\text { bank to which the PAC is linked }\end{array}$ & $\begin{array}{l}\text { More freedom and more } \\
\text { alternatives available. FPCs are } \\
\text { allowed to raise capital from } \\
\text { external sources }\end{array}$ \\
\hline $\begin{array}{l}\text { Relationship with } \\
\text { other business and } \\
\text { non-profit entities }\end{array}$ & Transaction based & $\begin{array}{l}\text { Producers and corporate/non-profit } \\
\text { entities can together float a } \\
\text { Producer Company }\end{array}$ \\
\hline
\end{tabular}

Sources: Department of Agriculture and Cooperation (2013); Dwivedi (1996); Mondal (2010); National Advisory Council (2012). 
Table 2 Major reason for formation of farmer producer company (FPC)

\begin{tabular}{|c|c|c|c|c|c|c|}
\hline \multirow[t]{2}{*}{ Major Reason } & \multicolumn{6}{|c|}{ Selected dairy based farmer producer company (FPC) } \\
\hline & FPC-1(n=24) & FPC $-2(n=24)$ & FPC $-3(n=24)$ & FPC-4(n=24) & FPC $-5(n=24)$ & Pooled $(n=120)$ \\
\hline $\begin{array}{l}\text { Farm inputs availability at } \\
\text { reasonable rate }\end{array}$ & $20(83.34)$ & $23(95.83)$ & $24(100.00)$ & $18(75.00)$ & $24(100.00)$ & 109(90.83) \\
\hline $\begin{array}{l}\text { Direct sale of farm } \\
\text { produce by eliminating middleman }\end{array}$ & $24(100.00)$ & $24(100.00)$ & $24(100.00)$ & $20(83.34)$ & $24(100.00)$ & $116(96.66)$ \\
\hline Capacity building & $7(29.17)$ & $24(100.00)$ & $20(83.34)$ & $20(83.34)$ & $20(83.34)$ & 91(75.83) \\
\hline Value addition & $5(20.83)$ & $24(100.00)$ & 22(91.67) & 22(91.67) & $20(83.34)$ & $93(77.50)$ \\
\hline $\begin{array}{l}\text { Benefits from various } \\
\text { govt. schemes }\end{array}$ & $13(54.17)$ & $24(100.00)$ & $24(100.00)$ & $24(100.00)$ & $24(100.00)$ & $109(90.83)$ \\
\hline Upliftment of women & $15(62.50)$ & $24(100.00)$ & $24(100.00)$ & $15(62.50)$ & $24(100.00)$ & $102(85.00)$ \\
\hline Reduced risk in farming & 14(58.33) & $24(100.00)$ & $22(91.67)$ & 19(79.17) & $24(100.00)$ & 103(85.83) \\
\hline Upgrade technology & 23(95.83) & $22(91.67)$ & 20(83.34) & $21(87.50)$ & $21(87.50)$ & 107(89.16) \\
\hline Storage facility & $14(58.33)$ & $20(83.34)$ & $22(91.67)$ & $20(83.34)$ & $6(25.00)$ & $82(68.33)$ \\
\hline $\begin{array}{l}\text { Credit facility from } \\
\text { company }\end{array}$ & $6(25.00)$ & $0(0.00)$ & $0(0.00)$ & $0(0.00)$ & $0(0.00)$ & $6(25.00)$ \\
\hline
\end{tabular}

Table 3: Selected dairy based farmer producer company and supporting agencies

\begin{tabular}{lllc}
\hline $\begin{array}{l}\text { Selected dairy based farmer } \\
\text { producer company }\end{array}$ & Supporting Agency & $\begin{array}{l}\text { Year of } \\
\text { initiation }\end{array}$ & Zone \\
\hline FPC-1 & NABARD & 2016 & Southern \\
FPC-2 & NABARD & 2016 & Southern \\
FPC-3 & Kudumbashree & 2016 & Central \\
FPC-4 & NABARD & 2016 & Central \\
FPC-5 & NABARD & 2013 & Northern \\
\hline
\end{tabular}

Table 4 Genesis of dairy based farmer producer companies

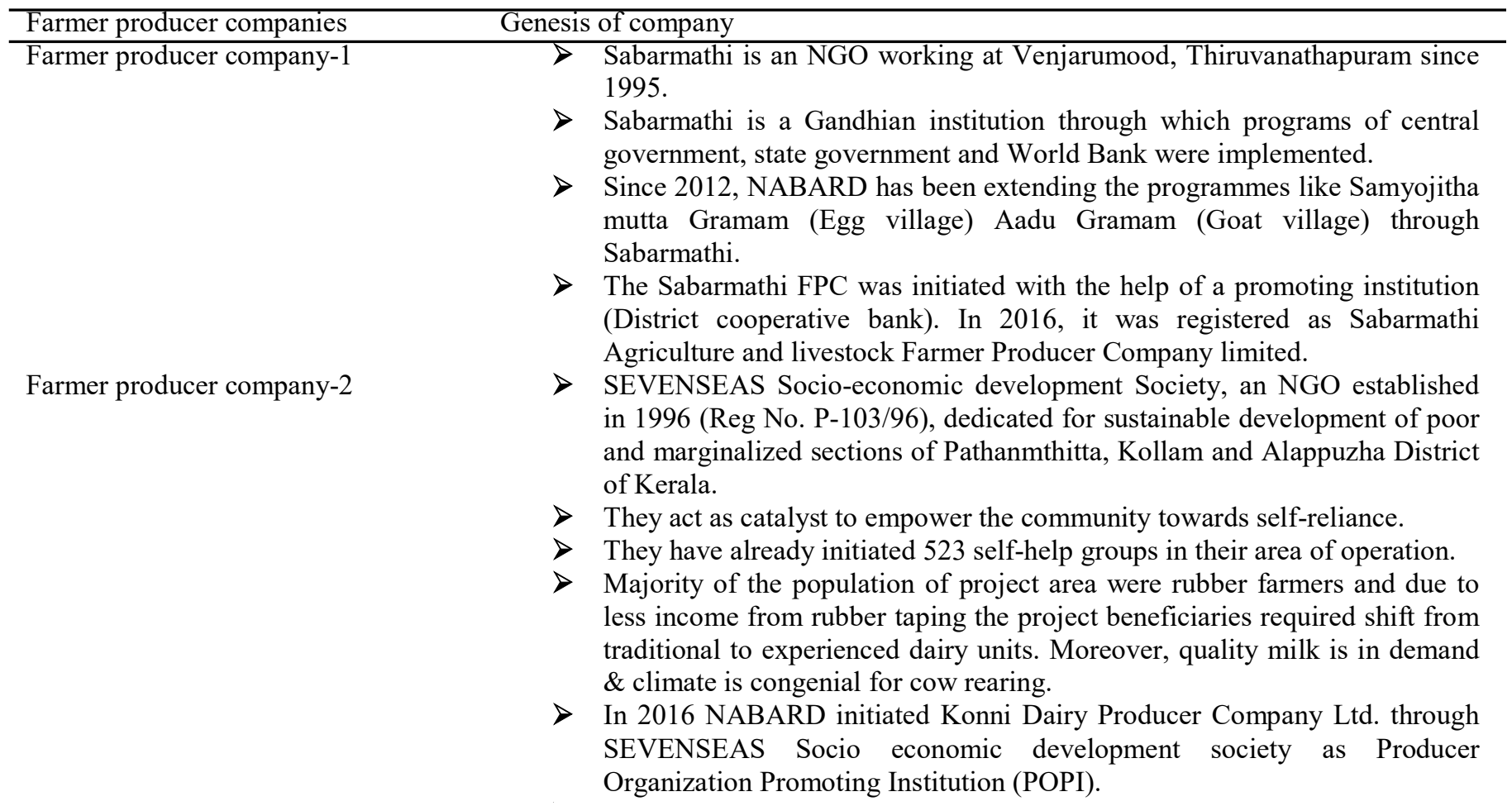


Farmer producer company-3

Farmer producer company-4

Farmer producer company-5

$>$ Kudumbashree district mission, Idukki, started Kudumbashree units for the betterment of woman dairy farmers.

$>$ A project named Ksheerasagaram was implemented in Kudumbashree units in 2012.

$>$ As a part of this project, kudumbashree units set up a 5 members group and to each group 10 cows were allotted.

$>$ But this programme did not fulfill expectations. In this situation a concept called milk Producer Company got initiated.

$>$ In 2016, with the support of Kudumashree district mission, Imasree milk Producer Company Ltd. was initiated.

$>$ Palakkad district is a rural area and most of the people depend on agriculture and dairy for their livelihood.

$>$ They were producing paddy, vegetables, coconut, banana, spices etc. The farmers sell their produce through middlemen and were not getting adequate income because they were exploited by middlemen.

$>$ To overcome this, NABARD initiated a producer company in that area.

$>$ In 2016, Jan Kissan Producer Company Ltd. Palakkad was registered.

$>$ Jan Kissan producer company produce products like milk \& milk products, compost, bio-fertilizers, organic manures, by products of cow dung \& cow urine.

$>$ Dairy farmers get Rs. 28-32/ liter of milk in cooperative societies. But in outside they get around Rs. 45/ liter. Farmers were exploited since they were deprived of actual price for their produce.

$>$ A self-help group namely Ksheerasagara was in existence for dairy promotion. But this programme did not fulfill expectations.

$>$ In 2013, members of Ksheerasagara, registered as BANA Agro \& Allied Farmer Producer Company Ltd. with the financial help of NABARD under rural infrastructure development fund

the tables.

\section{Reasons for formation of company}

Data presented in Table 2 indicates 10 major reasons for company formation. It is clearly indicated that 96.66 per cent of the respondents opined that direct sale of farm produce for maximum profit was the foremost reason of company formation and followed by availability of farm inputs at reasonable rate and benefits from various government schemes, through producer company $(90.83$ percent each). Other important reasons were upgraded technology $(89.16 \%)$, reducing risk in farming $(85.83 \%)$, upliftment of women $(85.00 \%)$, value addition $(77.50 \%)$, capacity building $(75.83 \%)$ and storage facility viewed by 68.33 percent of the respondents. Research evidence increasingly points to opportunities that farmer organizations create for small and marginal farmers to participate more effectively in markets (Stockbridge et al., 2003). Entry barriers to markets were also reportedly reduced through collective action of small and marginal farmers because of enhanced bargaining power (Kherallah et al., 2002; Thorp et al., 2005). Traditionally, small and marginal cultivators sold their produce at the farm gate, often to middlemen at low prices (Fafchamps and Hill, 2005).

\section{Brief description about genesis of selected companies}

Supporting agencies of selected farmer producer companies, their year of initiation and respective zones are described in Table 3.A brief description of genesis of each company is presented in the Table 4 .

\section{Conclusions}

The study reveals that 96.66 percent of respondents viewed direct sale of farm produce for maximum profit by elimination of middleman as the foremost reason of company formation closely followed by equally 90.83 percent availability of farm inputs at reasonable rate and benefits from various government schemes, through producer company. Other important reasons were upgraded technology, reducing risk in farming, upliftment of women, value addition, capacity building and storage facility. From the description we came to know that the earlier existed farmers group like self-help group which later get converted in to producer company with the help of supporting agencies like NABARD and Kudumbashree.

\section{References}

Fafchamps M, Hill RV (2005) Selling at the farm gate or traveling to market. American Journal of Agricultural Economics 87(3):717734 
Kherallah M, Delgado CL, Gabre-Madhin EZ, Minot N, Johnson M (2002) Reforming agricultural markets in Africa, Baltimore and London: The John Hopkins University Press

Mondal A (2010) Farmers' producer company (FPC) concept, practices and learning: A case from action for social advancement. Financing Agriculture 42(7) 29-33

Navaneetham B, Mahendran KK, Sivakumar SD, Senthilkumar R (2017) Status of farmer producer companies in India. Agric Update 12:888892

Farmer Producers' Organizations (FPOs): Status, Issues \& Suggested Policy Reforms, National Paper - PLP 2019-20, NABARD

Pustovoitova N (2011) Producer Company as an institutional option for small farmers in India'. Lunds Universitet
Stockbridge M, Dorward A, Kydd J, Morrison J, Poole N (2003) Farmer Organizatios for Market Access: An International review. London:Department of Agricultural Sciences,Imperial collage

Thorp R, Stewart F, Heyer A (2005) When and how far is group formation a route out of chronic poverty?', World Development 33(6):907920

Trebbin A (2014) Linking small farmers to modern retail through producer organizations-Experiences with producercompanies in India. Food Policy 45:35-44

Trebbin A, Hassler M (2012) Farmers' producer companies in India: A new concept for collective action? Environment and Planning Part A: Economy and Space 44:411-427 